\title{
EFFECTS OF VISUAL DEPRIVATION UPON THE MORPHOLOGY OF RETINAL GANGLION CELLS PROJECTING TO THE DORSAL LATERAL GENICULATE NUCLEUS OF THE CAT ${ }^{1}$
}

\author{
AUDIE G. LEVENTHAL ${ }^{* 2}$ AND HELMUT V. B. HIRSCH $\ddagger$ \\ * Department of Anatomy, University of Utah School of Medicine, Salt Lake City, Utah 84132 and $\ddagger$ Center for Neurobiology,
} State University of New York at Albany, Albany, New York 12222

Received July 15, 1982; Revised September 2, 1982; Accepted September 3, 1982

\begin{abstract}
Electrophoretic injections of horseradish peroxidase were made into physiologically characterized sites within the A laminae of the dorsal lateral geniculate nucleus (LGNd) of normal cats and of cats deprived from birth of vision in one eye by monocular lid suture (MD). MD cats were deprived for periods ranging from 2.5 to 14 months. The procedures employed involved staining the cell bodies, dendrites, and axons of retrogradely labeled retinal ganglion cells so that the morphology of cells in the two retinae could be compared. The geniculate laminae receiving afferents from the deprived eye were severely shrunken in all MD cats, confirming the effectiveness of the visual deprivation.

In MD cats, as in normal cats, the A laminae of the LGNd receive inputs from alpha and beta type ganglion cells. The relative numbers of alpha and beta cells projecting to the normal and deprived A laminae did not differ in any of the MD cats studied. Thus, the reported selective loss of $\mathrm{Y}$ cells from the deprived A laminae of MD cats is not paralleled by a change in the relative numbers of alpha and beta cells projecting to the A laminae.

In normal cats, the sizes of alpha and beta cells in one retina did not differ from those of their counterparts in the other retina. In MD cats, the areas of the cell bodies of alpha and beta cells in the deprived retina projecting to the binocular segments of the A laminae were, on average, 11.7 and $17.4 \%$ smaller, respectively, than their counterparts in the nondeprived retina. In MD cats, alpha cells in the deprived retina projecting to the monocular segment of lamina A were the same size as their counterparts in the nondeprived retina. In MD cats deprived for 7 to 12 months, the areas of the cell bodies of beta cells in the deprived retina projecting to the monocular segment of lamina $\mathrm{A}$ were, on average, $9.4 \%$ smaller than their normal counterparts and thus were affected less severely than beta cells in the deprived retina projecting to the binocular segment of lamina A. Within the limits of our technique, the dendritic fields and axons of alpha and beta cells in the deprived retina appeared normal.

These results indicate that the effects of MD upon the morphology of retinal ganglion cells are slight. However, it does appear that the effects of binocular competition upon the geniculocortical pathways are reflected in the cell body sizes of both alpha and beta cells and that the effects of other factors, such as deprivation per se or a competition between neighboring alpha and beta cells, are less severe than those of binocular competition.
\end{abstract}

The effects of depriving an animal of normal vision during its early life by suturing closed the lids of one eye (monocular deprivation or MD) have been studied at several sites along the visual pathways. MD produces

\footnotetext{
${ }^{1}$ This work was supported by National Institutes of Health Grants EY03427 to A. G. L. and EY01268 to H. V. B. H.

${ }^{2}$ To whom correspondence should be addressed at Department of Anatomy, Wintrobe Research Building, University of Utah School of Medicine, Salt Lake City, UT 84132.
}

both anatomical and physiological changes in the dorsal lateral geniculate nucleus (LGNd) (Guillery and Stelzner, 1970; Sherman et al., 1972) and in the visual cortex (Wiesel and Hubel, 1963, 1965). These changes provide evidence that there is a competition between the two eyes for control of cortical cells (Guillery and Stelzner, 1970 ) and that the LGNd relay cell types, $Y$ and $X$, are affected differently by MD (Sherman et al., 1972, 1975; for review see Hirsch and Leventhal, 1978).

In this study, we have examined the effects of MD on the alpha and beta cells in the retina that project to the 
$\Lambda$ laminac of the LGNd of the cat. Alpha and beta cells are morphological classes of retinal ganglion cells, are likely to correspond to the physiological types $\mathrm{Y}$ and $\mathrm{X}$ in the retina (Boycott and Wassle, 1974; Cleveland et al., 1976), and probably provide the excitatory afferent input to $\mathrm{Y}$ and $\mathrm{X}$ cells, respectively, in the LGNd A laminae (Cleland et al., 1971; Hoffmann et al., 1972).

Our results show that MD exerts an effect upon both alpha and beta cells and that the changes produced in portions of the retina subserving the binocular visual field differ from those produced in portions of the retina subserving the monocular visual field.

\section{Materials and Methods}

\section{Subjects}

Eight cats were deprived of vision in one eye by lid suture. Seven of the cats were deprived for 7 to 14 months (long-term MD) and one of the cats was deprived for 2.5 months (short-term MD). In all cases, the eyelids were sutured closed before the time of normal eye opening and were not opened until the day of the experiment. The sutured lids were checked regularly during the period of deprivation to make certain they remained closed. Three normal adult cats served as controls. Five of the MD cats and two of the normal cats received HRP injections into the LGNd. Three of the MD cats and one of the normal cats had their retinae stained with thionin.

\section{Surgery, electrophysiological recording, electrophoretic injection, histology and histochemistry}

These procedures have been described in detail elsewhere (Leventhal, 1982).

\section{Localization of injection sites}

In all animals, injections were made into the left and right LGNd into regions representing parts of the visual field between $5^{\circ}$ of azimuth and the far periphery. Since the vertical meridian is represented at the border between the medial interlaminar nucleus (MIN) and the laminated LGNd, avoiding the central $5^{\circ}$ of azimuth effectively excludes the MIN from the injection site.

Inspection of the injection sites confirmed that the spread of HRP involved both A laminae but avoided the MIN. There were no systcmatic differences between injections into the normal and deprived laminae. In some cases, secondary spread of HRP involved the $\mathrm{C}$ laminae and ventral LGN. This does not seriously affect the interpretation of our results for two reasons. First, results are presented separately for the nasal and temporal retina. Since alpha and beta cells in the temporal retina project to lamina A1 but not to lamina C1 (Leventhal, 1982), at least for the temporal retina, all labeled cells studied must have been labeled from lamina A1. Second, since alpha and beta cells do not project to the ventral LGN (Leventhal et al., 1981), an involvement of the ventral LGN in the injection site should not affect the present results.

Cell body measurement of HRP-filled cells. Ganglion cells were identified as alpha and beta using the criteria of Boycott and Wässle (1974). Alpha cells have large cell bodies, large and characteristic dendritic fields, and coarse axons. Beta cells have medium-sized cell bodies, small and characteristic dendritic fields, and medium gauge axons. In our HRP material, all labeled large cells and nearly all labeled smaller cells in the regions studied were stained well enough to identify and could be classified as alpha and beta, respectively (see Fig. 2). A few small and medium-sized cells were only lightly labeled and these could not be identified. These presumably represent cell types other than alpha and beta (gamma, epsilon, $\mathrm{g} 1, \mathrm{~g} 2$ ) which project to the $\mathrm{C}$ laminae (Leventhal, 1982). Very few well stained examples of these cell types were observed. The cell bodies of all cells stained well enough to classify as alpha or beta were measured until a sample of 40 cells of each type was accumulated. Cells were measured under the microscope using a calibrated eyepiece graticule and a $\times 100$ oil immersion objective. Measurements were made to the nearest micrometer in the plane of focus in which the cell's soma was largest. Cell body diameter was taken as the mean of the longest axis and of the orthogonal, shorter axis. The cell bodies of most beta cells appeared circular in our material; thus the two axes were usually similar. Many alpha cells did not appear circular primarily because the coarse initial segments of their dendrites were stained heavily and appeared continuous with their cell bodies. Thus, even though care was taken not to include the primary dendrites in the measurements, it must be assumed that the measurements of nearly all alpha cells and some beta cells were influenced by the initial segments of the labeled dendrites.

In each retina, cells were sampled from three regions of corresponding elevation ( 2 to $5 \mathrm{~mm}$ above the zero horizontal meridian). These sites were 4 to $7 \mathrm{~mm}$ from the zero vertical meridian in the temporal retina (cells projecting to the binocular segment of lamina A1) and 4 to $7 \mathrm{~mm}$ and 11 to $14 \mathrm{~mm}$ from the zero vertical meridian in the nasal retina (cells projecting to the binocular and monocular segments, respectively, of lamina A). It was necessary to sample cells in the nasal as well as temporal retina of both eyes since the sizes of HRP-stained alpha and beta cells in the nasal and temporal retina differ in the normal cat (Stone et al., 1980; Leventhal, 1982).

To eliminate the possible influence of experimenter bias upon cell size measurements, a second set of measurements was made in all MD cats receiving HRP injections using the following "blind" procedure. Photographs of corresponding regions of the ganglion cell layers of the two retinae were taken using $4 \times 5$ positive-negative (Polaroid type 55) film. Only regions that contained comparable labeling were photographed. On the final print, $1 \mathrm{~mm}$ corresponded to approximately $2 \mu \mathrm{m}$. Enlargements were made on number 1 photographic paper in order to preserve as much detail as possible. The enlargements were coded and given to an uninformed student for measurement. The areas of all labeled alpha and beta cells in each photograph were measured using a Numonics model 1224 electronic digitizer.

Cell body measurements of Nissl-stained cells. The cell bodies of Nissl-stained "giant" ganglion cells were measured in six retinae from three MD cats and two retinae from a normal cat. Most "giant" ganglion cells are likely to be alpha cells. However, a few of the cells 
judged to be "giant" ganglion cells were 28 to $30 \mu \mathrm{m}$ in diameter and thus could have been beta or epsilon cells. Measurements of Nissl-stained cells were made as described above for HRP-stained cells under the microscope using a calibrated eyepiece graticule. The "blind" procedure described above was not employed since, in the Nissl-stained retinae, the borders of the cell bodies were not easily determined from the enlargements. Even under the microscope, the borders of the cell bodies of Nissl-stained cells in whole mount retinae appear less distinct than those of cells heavily stained with HRP. The cell bodies of most Nissl-stained "giant" ganglion cells appear roughly circular; thus the diameter measurements for these cells provide an indication of the areas of their cell bodies.

We did not measure any cells other than "giant" ganglion cells in Nissl-stained material. Other ganglion cell types in the cat retina range in diameter from 10 to 32 $\mu \mathrm{m}$, and the distributions of cell body sizes of the different types (beta, gamma, episilon, g1, g2) overlap to a great extent (Leventhal, 1982). Moreover, distinguishing small ganglion cells from glial cells is a problem in Nissl-stained retinae. Thus, for small and medium-sized cells, identification based upon cell size alone would not have yielded interpretable results.

Dendritic field measurements. In two long-term MD cats receiving $\mathrm{HRP}$ injections, the dendritic fields of 10 to 20 alpha and 10 to 20 beta cells in each retina were measured under the microscope using a calibrated eyepiece graticule and a $\times 40$ oil immersion planapochromatic objective. In one cat, cells sampled wore 5 to $7 \mathrm{~mm}$ from the area centralis in the temporal retina. In the other cat, cells sampled were 5 to $7 \mathrm{~mm}$ from the area centralis in the nasal retina. For each dendritic field, the diameter along its longest axis was measured. Since the dendritic fields of most cells in Golgi material are approximately circular (Boycott and Wässle, 1974) and not all of the cells in our material were completely filled, the long axis is likely to provide the most accurate indication of the dendritic field size of filled cells. Only the best of the stained cells were sampled for dendritic field measurement, and the dendritic fields of these cells did, in fact, tend to be symmetrical (Figs. 4 and 5).

Axon measurements. The diameters of HRP-stained axons were measured under the microscope, using a $\times 20$ eyepience, a calibrated eyepiece graticule, and a $\times 100$ oil immersion objective. Axons were measured distal to the axon hillock at a point past the axon's initial taper. All measurements were made between the regularly spaced swellings that were visible along the axons. The point at which the measurements are made must be comparable for all cells since an axon's diameter at a swelling can be twice its diameter between swellings. Using these techniques, measurements are theoretically accurate to within $0.2 \mu \mathrm{m}$. The actual accuracy in our material may be less. Forty alpha and 40 beta cells were sampled from the normal and deprived eyes of two cats, MD2 and MD3. Axons were sampled from two regions in each retina. Both regions were 4 to $7 \mathrm{~mm}$ from the area centralis. One was in the nasal and one was in the temporal retina. All stained axons were measured until a sample of 20 was accumulated from each region.
Density of labeled cells. In all MD cats, the numbers of labeled alpha and beta cells were determined in those regions of the retina from which cells were samples for measurement (see above). Within each region all alpha and beta cells visible within in $a \times 0.10 .1-\mathrm{mm}$ eyepiece grid first were counted. A number of adjacent areas then were sampled in a spiral pattern centered upon the initial grid region until 200 to 300 cells were counted.

Laminar width measurements. The width of the normal and deprived A laminae were measured in all MD cats. A laminar width ratio (width of normal lamina/ width of deprived lamina) then was computed. Each value was based on a mean of five measurements taken from five adjacent sections in the part of the LGNd containing the injection sites. This corresponded roughly to coronal level 6 of Sanderson (1971). Measurements in the binocular segment were made orthogonal to the $\mathrm{A}$ laminae approximately $2 \mathrm{~mm}$ from the medial border of the laminated LGN. Measurements in the monocular segment of lamina A were made in the mediolateral direction, orthogonal to the tail of lamina A, just below lamina $\mathrm{A} 1$. This region represents azimuths of greater than $50^{\circ}$ (Sanderson, 1971). One millimeter of cat retina subtends roughly $4.5^{\circ}$ of visual angle; thus 11 to $14 \mathrm{~mm}$ from the zero vertical meridian (the region of retina studied) projects to this part of the monocular segment. This part of the monocular segment is reported to be especially insensitive to visual deprivation in MD cats (Kalil, 1980).

Statistical analyses. In order to determine the extent to which the differences observed were due to random variations among animals and not to the deprivation, the following statistical analyses were used. First, the mean cell size for each sample was computed. One value then was obtained for each cat by subtracting the mean for the sample of cells from the deprived eye from the mean for the corresponding sample of cells from the normal eye (i.e., Table III, column labeled $\bar{X}$ normal - column labeled $\overline{\mathrm{X}}$ deprived). The resulting differences between the two eyes then were tested against zero using a two tailed $t$ test. This procedure provides a conservative means of determining, for the MD cats, whether the cells sampled from the deprived eye were smaller than those of their normal counterparts.

In order to compare the effects of deprivation upon alpha and beta cells, a similar analysis was performed. First, the percentage of change in size for corresponding samples of cells in the normal and deprived eyes was computed. Then, for each cat, the percentage of change for alpha cells was subtracted from the percentage of change for neighboring beta cells. The resulting values, one for each cat, were tested against zero using a two tailed $t$ test. The sizes of cells projecting to the binocular and monocular segments of lamina A were compared in a similar fashion. The percentage of difference between corresponding samples of cells in the normal and deprived eyes first was computed. Then, for example, the value for beta cells projecting to the monocular segment was subtracted from the value for beta cells, in the same cat, projecting to the binocular segment. The resulting values, one for each cat, were tested against zero. Whenever possible, statistical analyses were carried out sepa- 

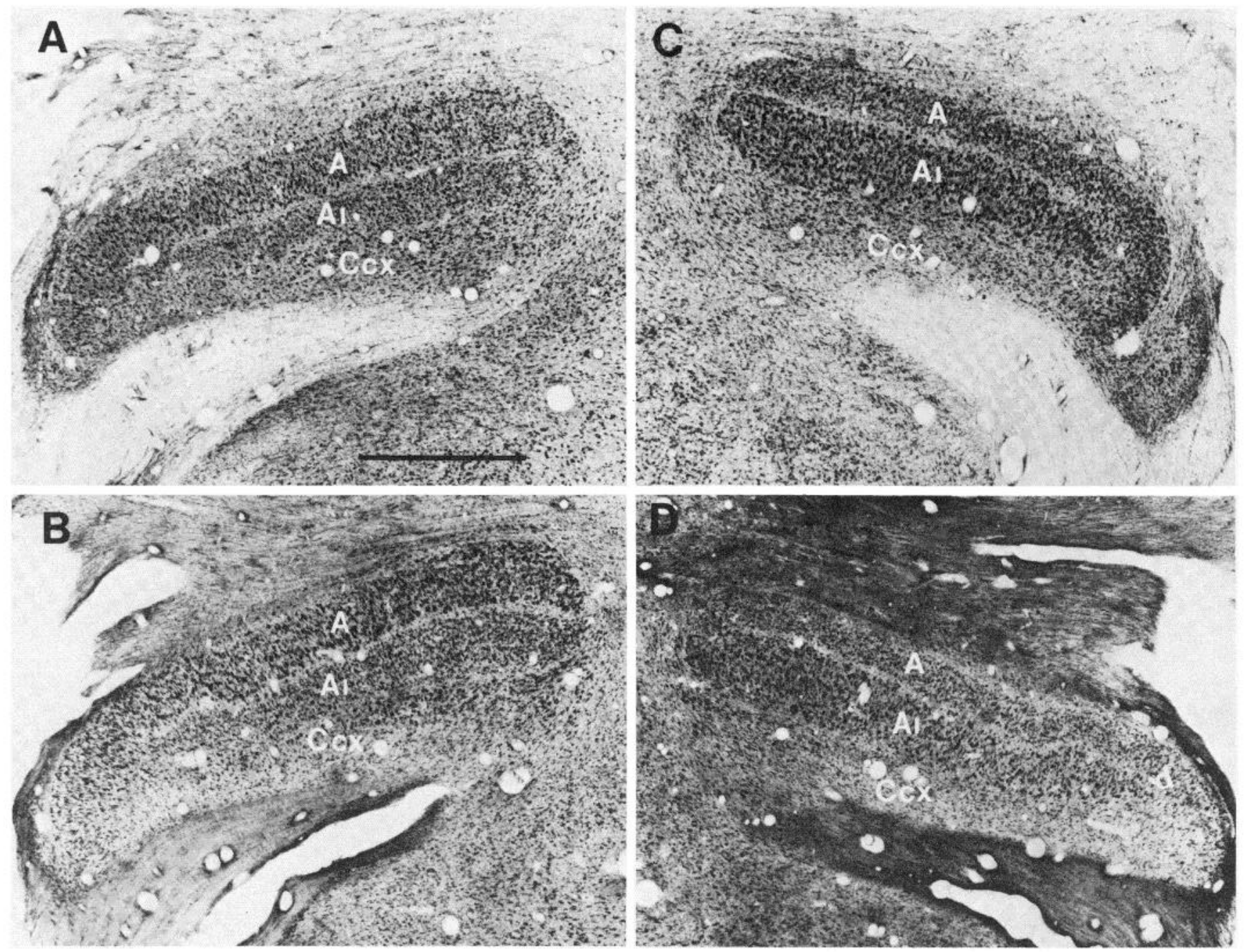

Figure 1. Photomicrographs of Nissl-stained coronal sections through the LGNd of cats MD1 $(A$ and $C)$ and MD2 $(B$ and $D$ ). The sections shown in $A$ and $B$ are ipsilateral to the deprived eye (lamina $\mathrm{Al}$ is deprived) and those in $C$ and D are contralateral to the deprived eye (lamina A is deprived). Scale bar, $1 \mathrm{~mm}$. $A$ to $D$ are at the same magnification. Notice that the laminae innervated by the deprived eye are reduced in width, especially in regions of the nucleus subserving binocular vision.

rately on diameter measurements made under the microscope and on the area measurements made using the "blind procedure" described in a foregoing section. We feel that both techniques have their advantages. The measurements made directly under the microscope provide the most accurate means of determining the borders of labeled cells, while the area measurements, although somewhat less accurate, are free from experimenter bias. All values given in the text are based upon the analysis described above in which one value was derived for each cat.

In order to determine if the differences between the two eyes in the individual cats were significant, we have also compared corresponding samples of cells in the two eyes using a two tailed $t$ test. The resulting significance values are given in Tables III and IV.

\section{Results}

To verify that MD had been effective in all animals, Nissl-stained sections were taken from the right and left
TABLE I

Laminar width ratios (width of normal lamina/width of deprived lamina) for MD cats in this study ${ }^{a}$

\begin{tabular}{lccc}
\hline Cat & A (Binocular) & A1 (Binocular) & A (Monocular) \\
\hline MD1 & 1.51 & 1.68 & 1.19 \\
MD2 & 1.41 & 1.56 & 1.27 \\
MD3 & 1.52 & 1.57 & 1.20 \\
MD4 & 1.42 & 1.51 & 1.19 \\
MD5 & 1.49 & 1.44 & 1.17 \\
MD6 & 1.45 & 1.46 & 1.11 \\
MD7 & 1.45 & 1.55 & 1.21 \\
MD9 & 1.37 & 1.55 & 1.21 \\
\hline
\end{tabular}

${ }^{a}$ A ratio of 1.0 indicates that the deprivation had no effect on laminar width; progressively higher ratios indicate progressively greater effects.

LGNd of each cat and the laminae receiving afferents from the two eyes were compared. Representative sections taken from two cats are shown in Figure 1. These sections are close to those containing the injection sites 
and represent parts of the visual field just below the zero horizontal meridian. In all cats, the regions of the retina projecting to the illustrated portion of the LGNd contained a high concentration of labeled cells; it was in these regions of the retina that measurements of alpha and beta cells were made.
In all MD animals studied, the deprived laminae were shrunken relative to the normal laminae in a fashion typical of that reported previously for MD cats (Guillery and Stelzner, 1970). The deprived laminae were reduced in width (Table I and Fig. 1) and contained few large cells. The magnitude of the effects of MD on laminae A

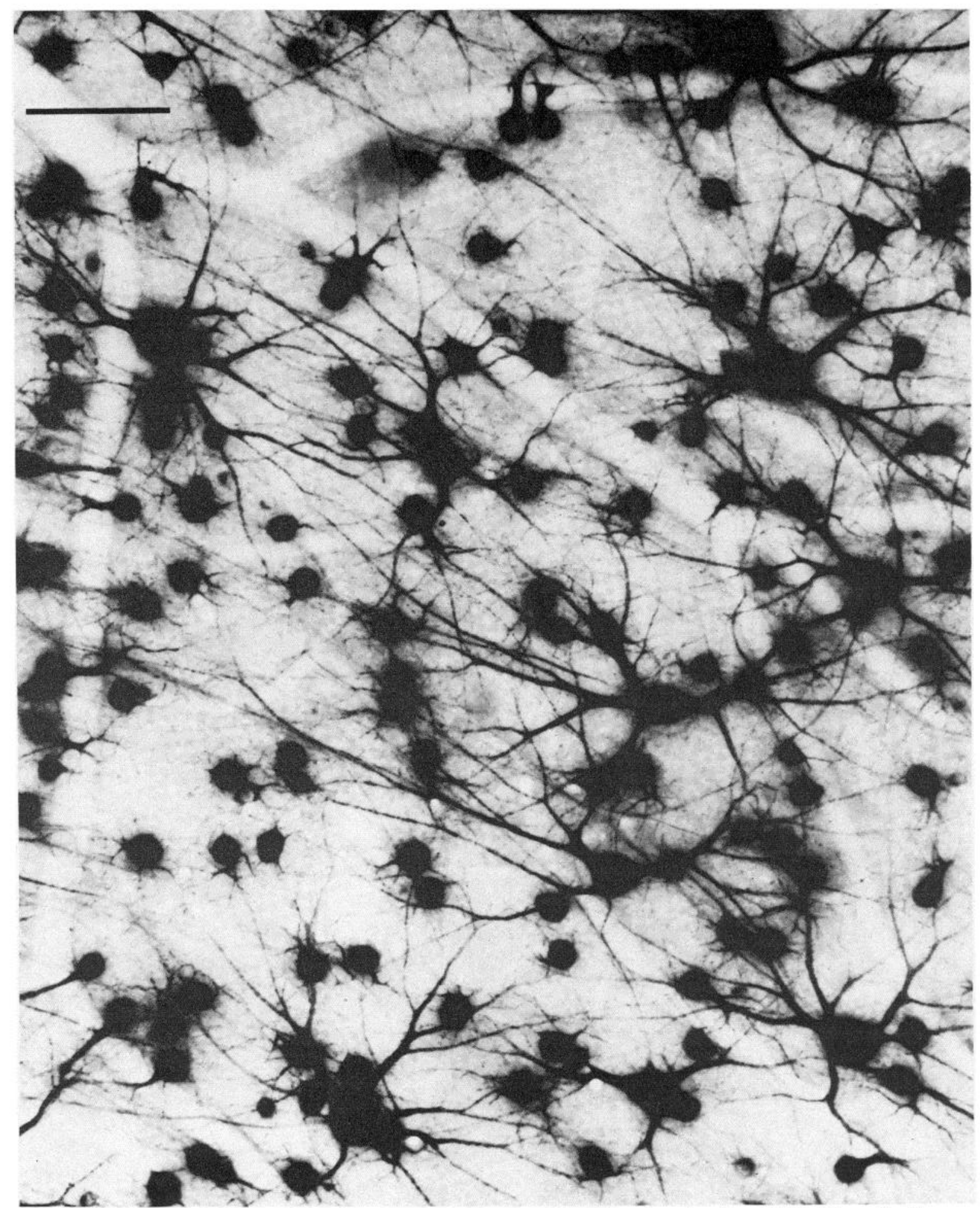

Figure 2. Alpha and beta cells labeled by injections of HRP into deprived lamina A1 of cat MD3. The cells shown are 4 to 5 $\mathrm{mm}$ from the area centralis. Scale bar, $100 \mu \mathrm{m}$. The relative and absolute numbers of alpha and beta cells projecting to the deprived laminae of the LGNd appear normal. 
and Al were similar, but in seven of the eight cats, lamina A1 was slightly more shrunken than lamina A (see also Hickey, 1980). In all cases the monocular segment of lamina A was affected less than the binocular segment.

Relative numbers of alpha and beta cells. The numbers of alpha and beta cells projecting to the A laminae were the same for the deprived and nondeprived retina. Figure 2 illustrates the distribution of labeled ganglion cells in the deprived retina of one cat. The relative numbers of alpha and beta cells projecting to the binocular segments of the normal and deprived A laminae for all cats are presented in Table II. No consistent differences between the normal and the deprived retinae were evident in either the relative or absolute numbers of labeled alpha and beta cells; the values obtained for both eyes of all MD cats are comparable to those for normal animals (Leventhal, 1982).

Cell body size measurements. In normal cats, there were no significant differences in the sizes of alpha and beta cells in the two retinae (Table III). Even in Siamese cats (Leventhal, 1982), the cell body sizes of alpha and bela cells in one retina do not differ from those of their counterparts in the other retina.

In $\mathrm{MD}$ cats receiving $\mathrm{HRP}$ injections, the soma diameters of both alpha and beta cells in the deprived retina projecting to the binocular segments of laminae $A$ and Al were smaller than those of their counterparts in the nondeprived retina (Table III). Comparisons of corresponding samples of cells in the two eyes indicate that, for the nasal and temporal retina, differences in diameter were significant at the $0.001(t=8.8 ; d f=4)$ and 0.0005 $(t=11.6 ; d f=4)$ levels, respectively, for alpha cells, and at the $0.0005(t=12.2 ; d f=4)$ and $0.005(t=6.3 ; d f=4)$ levels, respectively, for beta cells. Measurements of area yielded similar results (Table IV). Differences in area between corresponding samples of alpha cells in the two eyes were significant at the 0.006 level $(t=5.4 ; d f=4)$. Differences between corresponding samples of beta cells in the two eyes were significant at the $0.01(t=4.3 ; d f=$ 4) level.

In regions of the deprived retina subserving binocular vision in the adult MD cats, beta cells were affected somewhat more severely than alpha cells. When all MD cats were considered, the percentage of decrease in the diameters as well as areas of the cell bodies of beta cells in the deprived eye was greater than the decrease for alpha cells (Tables III and IV). In the binocular segments of the nasal and temporal retina, differences in diameter were significant at the $0.002(t=7.4 ; d f=4)$ and $0.04(t$ $=3.3 ; d f=4$ ) levels, respectively. For area measurements, differences between alpha and beta cells did not reach significance ( $p<0.2 ; t=1.8 ; d f=4)$. This is because in the 2.5-month-old $\mathrm{MD}$ kitten studied, area measurements indicated that alpha and beta cells projecting to the binocular segment of lamina A were shrunken to the same extent. The distributions of cell body diameters of alpha and beta cells in the two retinae of a typical adult MD cat are given in the histograms presented in Figure 3. Summaries of the sizes of alpha and beta cells in all MD cats are given in Tables III and IV.

In the group of MD cats in this study, the cell body diameters and areas of alpha cells in the deprived retina
TABLE II

Alpha/beta ratios (number of labeled alpha cells/number of labeled alpha cells + number of labeled beta cells) in nasal and temporal areas of the retinae of the $M D$ cats in this study

All animals received injections of HRP into the A laminae of the LGNd in both hemispheres. Values are based upon samples of 200 to 400 cells. Cells were counted in regions of the retina located 4 to $7 \mathrm{~mm}$ from the area centralis.

\begin{tabular}{ccccc}
\hline Cat & $\begin{array}{c}\text { Deprived } \\
\text { Temporal } \\
\text { Retina }\end{array}$ & $\begin{array}{c}\text { Normal } \\
\text { Temporal } \\
\text { Retina }\end{array}$ & $\begin{array}{c}\text { Deprived } \\
\text { Nasal } \\
\text { Retina }\end{array}$ & $\begin{array}{c}\text { Normal } \\
\text { Nasal } \\
\text { Retina }\end{array}$ \\
\hline MD1 & 0.079 & 0.083 & 0.093 & 0.087 \\
MD2 & 0.087 & 0.086 & 0.098 & 0.107 \\
MD3 & 0.100 & 0.096 & 0.106 & 0.108 \\
MD4 & 0.092 & 0.088 & 0.103 & 0.110 \\
MD9 & 0.081 & 0.082 & 0.093 & 0.097 \\
\hline
\end{tabular}

projecting to the monocular segment of lamina A did not differ from those of their counterparts in the nondeprived retina. On the other hand, when all MD cats, regardless of age, were considered, there is some evidence that beta cells in the deprived relina projecling to the monocular segment of lamina A were smaller than their counterparts of the nondeprived retina $(p<0.01 ; t=5.0 ; d f=4-$ diameter; $p<0.04 ; t=3.3 ; d f=4-$ area). These significance values must be interpreted cautiously since in the 2.5-month old MD kitten, the sizes of beta cells in the monocular segments of the normal and deprived eyes did not differ (Tables III and IV). If only the four longterm MD cats are considered, then the differences between beta cells in the two eyes projecting to the monocular segment of lamina A are more convincing $(p<$ $0.005 ; t=7.7 ; d f=3$ - diameter; $p<0.0001 ; t=52.0 ; d f$ $=3-$ area). Finally, although beta cells in the deprived retina projecting to the monocular segment of lamina A were affected by the deprivation, they were affected less severely than beta cells in the same retina projecting to the binocular segment of lamina A $(p<0.002 ; t=7.2$; $d f$ $=4$ - diameter; $p<0.05 ; t=2.8 ; d f=4-$ area).

In three MD cats deprived for 13 to 14 months and one normal adult cat, the cell body diameters of Nisslstained "giant" ganglion cells were measured (Table III). In the normal cat, the sizes of the cell bodies of "giant" ganglion cells in the two retinae did not differ. Similarly, in the MD cats, "giant" ganglion cells in the two retinae subserving monocular vision did not differ in any of the cats studied. In contrast, cells in regions of the deprived retina subserving binocular vision tended to be smaller than their normal counterparts. In the temporal retina, the differences between the two eyes were significant in all three cats (Table III). However, in the nasal retina, a significant difference between the two cyes was evident in only one of the three cats studied. Thus, the results of measurements in the Nissl-stained retinae, although small and variable, are consistent with those in the HRP material.

The foregoing results of measurements in Nissl-stained material must be interpreted cautiously for a number of reasons. First, the borders of the cell bodies of Nisslstained cells are not always distinct in whole mount preparations. Second, the cell bodies of Nissl-stained "giant" ganglion cells can be as small as 28 to $30 \mu \mathrm{m}$. 


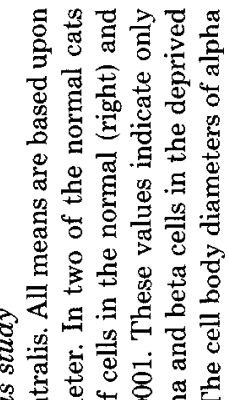

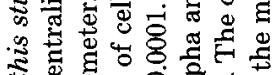

ङ

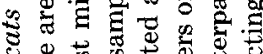

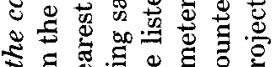

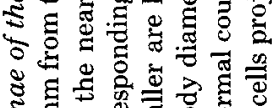

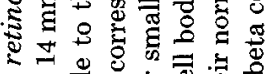

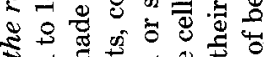

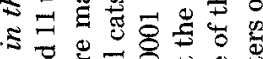

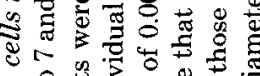

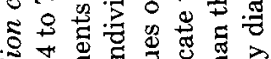

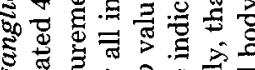

w

충

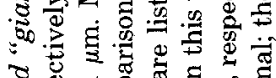

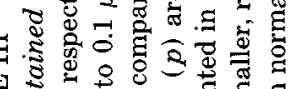

.
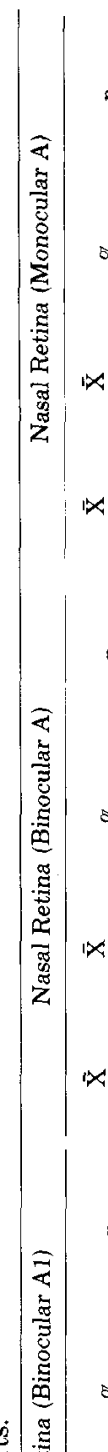

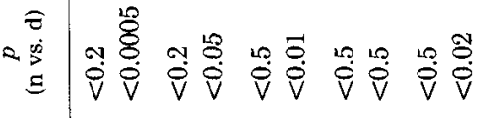

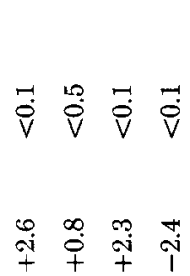

象莺

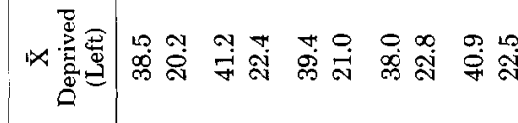

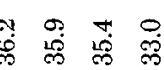

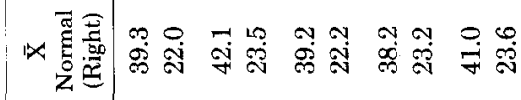

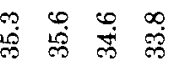

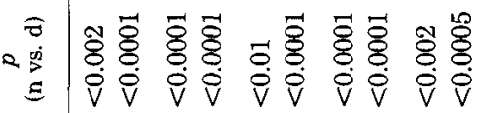

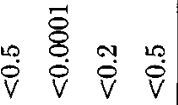

$\bar{\tau}$
$\frac{\pi}{\pi}$
$\frac{\pi}{\pi}$

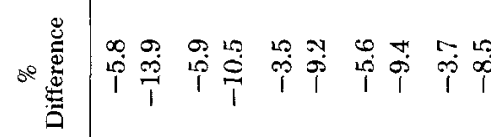

$\stackrel{0}{i} \stackrel{0}{i} \stackrel{\vec{T}}{i} \stackrel{0}{+}$

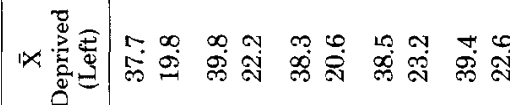

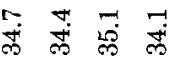

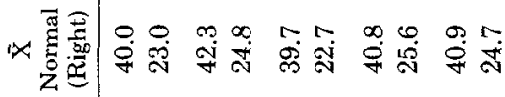

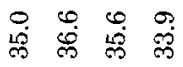

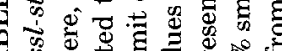

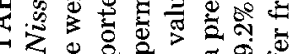

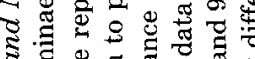

今.

ष 40

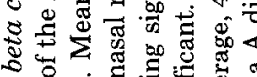

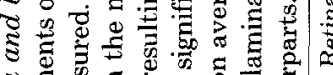

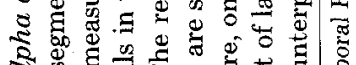

वे.

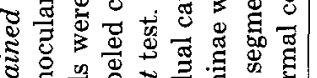

\%

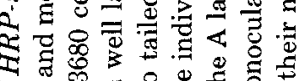

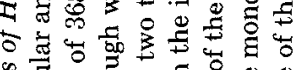

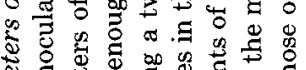

z)

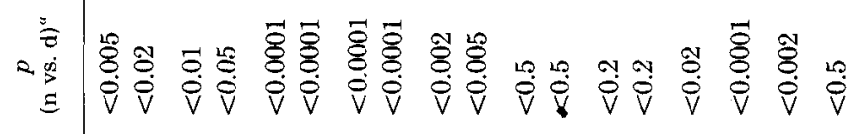

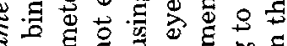

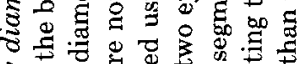

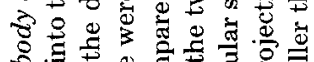

类

今.

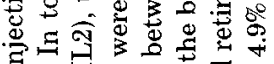

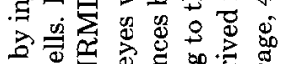

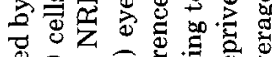

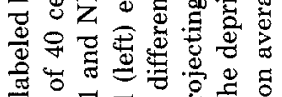

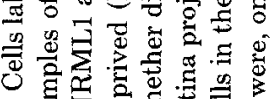

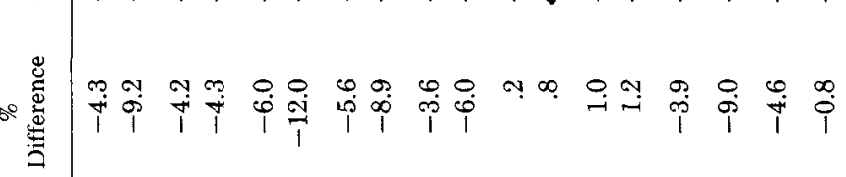

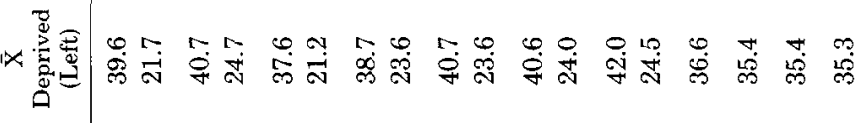

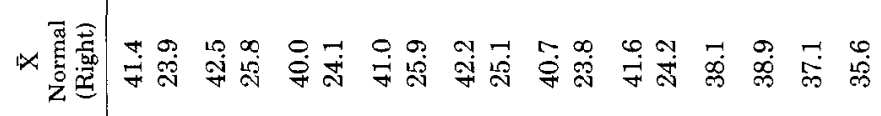

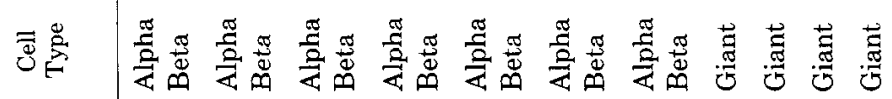

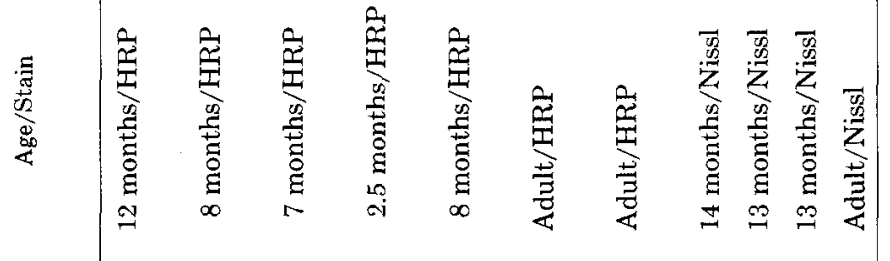

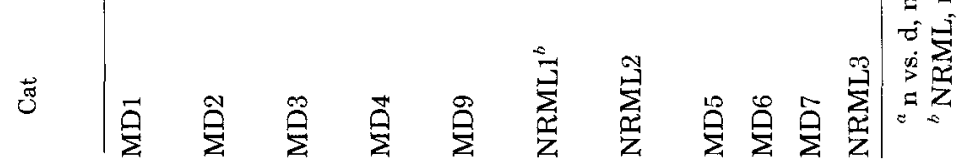


TABLE IV

Areas of alpha and beta cells labeled by injections of HRP into lamina $A$ and A1 of five MD cats ${ }^{a}$

This lable is based upon measurements of 3237 cells. Sample sizes differed, depending upon the numbers of alpha and beta cells in the photographs upon which they were based. Significance values $(p)$ were determined as described in the legend to Table III. The data presented in this table indicate that the areas of alpha and beta cells in the deprived retina projecting to the binocular segments of the A laminae were, respectively, 11.7 and $17.4 \%$ smaller than those of their normal counterparts. The areas of alpha cells in the deprived retina projecting to the monocular segment of lamina A did not differ from normal. In long-term MD cats, the areas of beta cells in the deprived retina projecting to the monocular segment of lamina A were, on average, $9.4 \%$ smaller than those of their normal counterparts.

\begin{tabular}{|c|c|c|c|c|c|c|c|c|c|c|}
\hline Cat & Age/Stain & $\begin{array}{l}\text { Cell } \\
\text { Type }\end{array}$ & \multicolumn{4}{|c|}{$\begin{array}{l}\text { Nasal and Temporal Retina } \\
\text { (Binocular A and A1) }\end{array}$} & \multicolumn{4}{|c|}{ Nasal Retina (Monocular A) } \\
\hline MD1 & 12 months/HRP & $\begin{array}{l}\text { Alpha } \\
\text { Beta }\end{array}$ & $\begin{array}{r}1240.8 \\
348.2\end{array}$ & $\begin{array}{r}1120.8 \\
305.8\end{array}$ & $\begin{array}{r}-9.7 \\
-12.2\end{array}$ & $\begin{array}{l}<0.005 \mathrm{~N}^{b} \\
<0.04 \mathrm{~N}\end{array}$ & $\begin{array}{r}1001.8 \\
332.7\end{array}$ & $\begin{array}{l}998.6 \\
299.0\end{array}$ & $\begin{array}{r}-0.3 \\
-10.1\end{array}$ & $\begin{array}{l}<0.5 \\
<0.005\end{array}$ \\
\hline MD2 & 8 months/HRP & $\begin{array}{l}\text { Alpha } \\
\text { Beta }\end{array}$ & $\begin{array}{r}1356.6 \\
418.8\end{array}$ & $\begin{array}{r}1254.4 \\
316.4\end{array}$ & $\begin{array}{r}-7.5 \\
-24.4\end{array}$ & $\begin{array}{l}<0.2 \mathrm{~N} \\
<0.0001 \mathrm{~N}\end{array}$ & $\begin{array}{r}1145.0 \\
408.0\end{array}$ & $\begin{array}{r}1320.4 \\
373.2\end{array}$ & $\begin{array}{r}+15.3 \\
-8.5\end{array}$ & $\begin{array}{l}<0.1 \\
<0.05\end{array}$ \\
\hline MD3 & 7 months/HRP & $\begin{array}{l}\text { Alpha } \\
\text { Beta }\end{array}$ & $\begin{array}{r}1191.6 \\
455.3\end{array}$ & $\begin{array}{l}953.3 \\
328.1\end{array}$ & $\begin{array}{l}-20.0 \\
-27.9\end{array}$ & $\begin{array}{l}<0.02 \mathrm{~T} \\
<0.0001 \mathrm{~T}\end{array}$ & $\begin{array}{r}1137.4 \\
369.4\end{array}$ & $\begin{array}{r}1157.6 \\
332.6\end{array}$ & $\begin{array}{r}+1.8 \\
-10.0\end{array}$ & $\begin{array}{l}<0.5 \\
<0.05\end{array}$ \\
\hline MD4 & 2.5 months/HRP & $\begin{array}{l}\text { Alpha } \\
\text { Beta }\end{array}$ & $\begin{array}{r}1346.9 \\
448.4\end{array}$ & $\begin{array}{r}1152.4 \\
389.1\end{array}$ & $\begin{array}{l}-14.4 \\
-13.2\end{array}$ & $\begin{array}{l}<0.0005 \mathrm{~N} \\
<0.0005 \mathrm{~N}\end{array}$ & $\begin{array}{l}971.9 \\
321.5\end{array}$ & $\begin{array}{l}978.7 \\
327.0\end{array}$ & $\begin{array}{l}+0.7 \\
+1.7\end{array}$ & $\begin{array}{l}<0.5 \\
<0.5\end{array}$ \\
\hline MD9 & 8 months/HRP & $\begin{array}{l}\text { Alpha } \\
\text { Beta }\end{array}$ & $\begin{array}{r}1390.5 \\
443.4\end{array}$ & $\begin{array}{r}1293.6 \\
402.2\end{array}$ & $\begin{array}{l}-7.0 \\
-9.3 \\
\end{array}$ & $\begin{array}{l}<0.2 \mathrm{~T} \\
<0.005 \mathrm{~T}\end{array}$ & $\begin{array}{r}1155.4 \\
405.7 \\
\end{array}$ & $\begin{array}{r}1036.3 \\
369.7\end{array}$ & $\begin{array}{r}-10.3 \\
-8.9\end{array}$ & $\begin{array}{l}<0.2 \\
<0.004\end{array}$ \\
\hline
\end{tabular}

${ }^{a}$ These cats are also included in Table III.

${ }^{b} \mathrm{n}$ vs. d, normal vs. deprived.

" $\mathrm{N}$ or 'T' following significance values indicate whether cells were sampled from the nasal or temporal retina, respectively (4 to $7 \mathrm{~mm}$ from the area centralis).
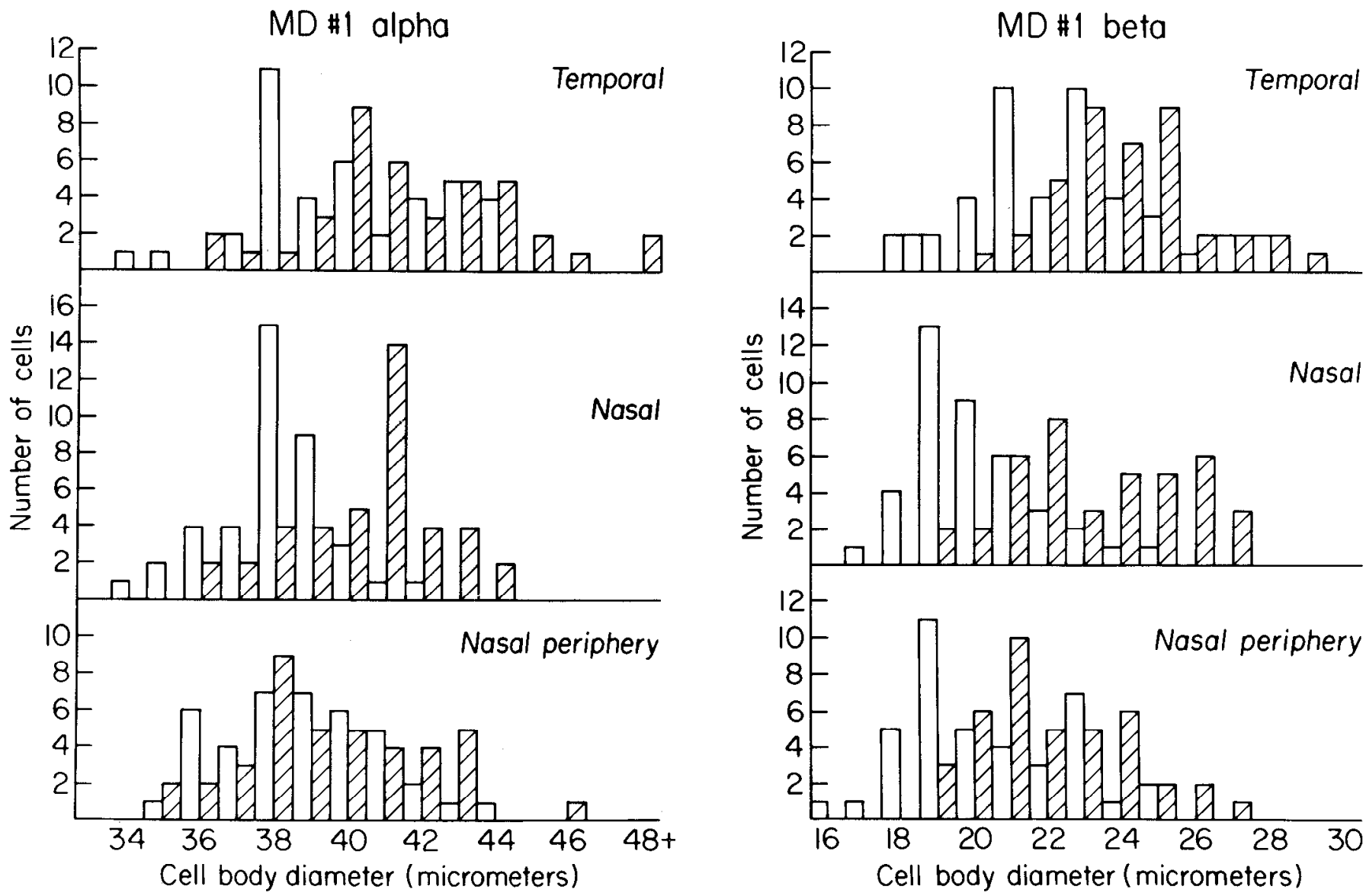

Figure 3. Histogram of cell body sizes of alpha (left) and beta (right) cells projecting to the nondeprived (solid bars) and deprived (open bars) A laminae in cat MD1. Top, Cells are 4 to $7 \mathrm{~mm}$ from the area centralis in the temporal retina. Cells were labeled by injections into the binocular segment of lamina A1. Middle, Cells are 4 to $7 \mathrm{~mm}$ from the area centralis in the nasal retina. These cells were labeled by injections into the binocular segment of lamina A. Bottom, Cells are 11 to $14 \mathrm{~mm}$ from the area centralis in the nasal retina. These cells were labeled by injections into the monocular segment of lamina A. East histogram is based upon a sample of 40 cells from the nondeprived retina and 40 cells from the deprived retina. 
Since other cell types in the cat retina (beta, epsilon) can be this large, it is possible that some of the "giant" ganglion cells sampled were not alpha cells or that some cells which appeared too small to be "giant" ganglion cells were alpha cells. Finally, unlike the HRP-stained retinae, cells sampled in Nissl-stained retinae may not all project to the lateral geniculate nucleus and thus may nol all be affected by MD in the same way. These difficulties, combined with the small size of the effect of $\mathrm{MD}$ upon ganglion cell size, make it unlikely that meas- urements in Nissl-stained retinac, even in a large number of cats, can alone yield convincing results.

Dendritic morphology. In the MD cats studied, the dendritic fields of many labeled alpha and beta cells were stained well enough to allow comparisons between cells in the normal and deprived retinae. The camera lucida drawings in Figures 4 and 5 are representative of cells labeled by injections into the normal and deprived $A$ laminae. These drawings provide an indication of the detail generally evident in our material. They show that

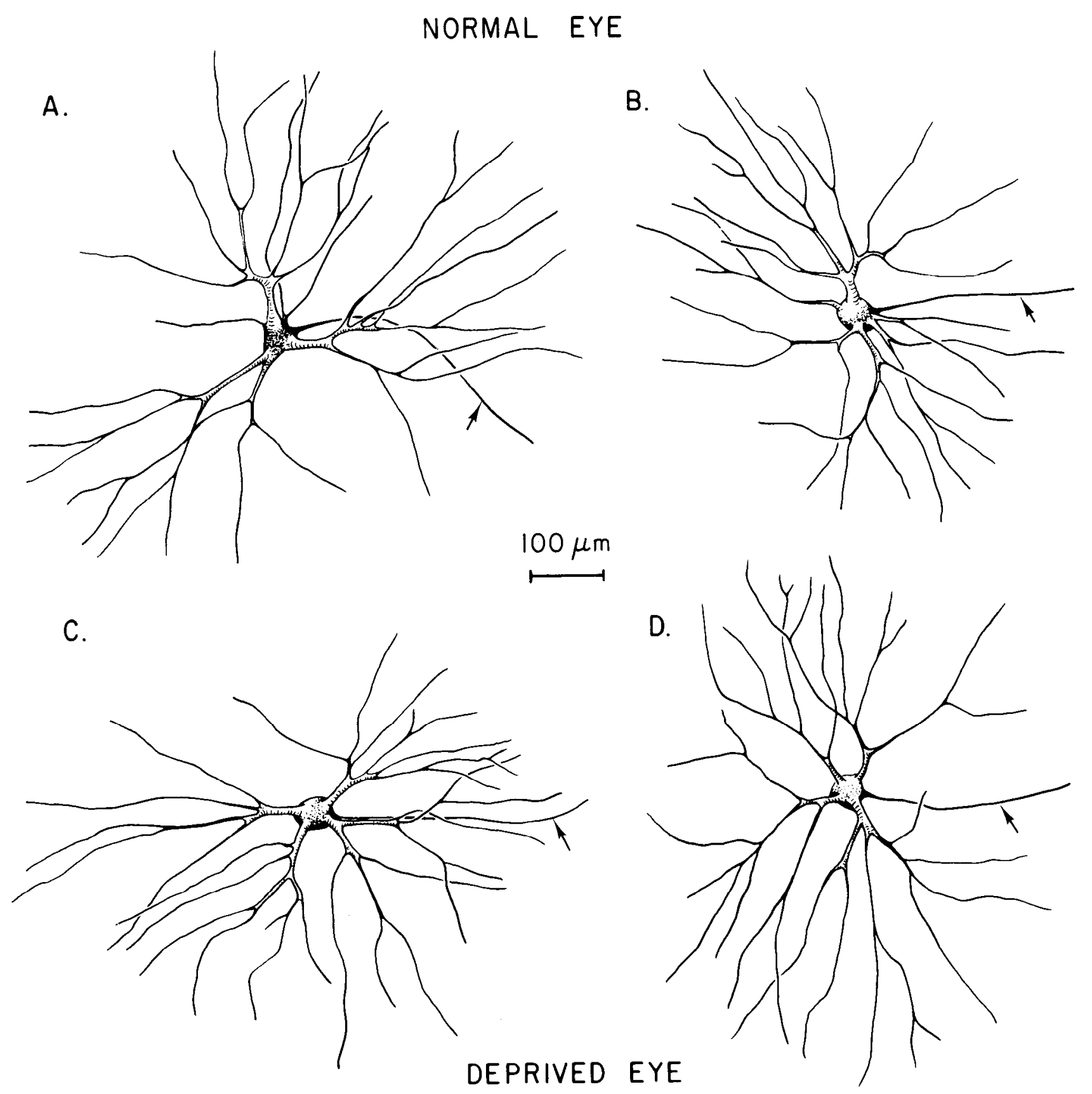

Figure 4. Camera lucida drawings of alpha cells labeled by injections of HRP into the nondeprived $(A$ and $B)$ and deprived $(C$ and $D$ ) A laminae of cat MD3. The cells in $A$ and $C$ were labeled by an injection into lamina A1 and were located 5 to $7 \mathrm{~mm}$ from the area centralis in the temporal retina. The cells in $B$ and $D$ were labeled by an injection into lamina A and were located 5 to $7 \mathrm{~mm}$ from the area centralis in the nasal retina. Each cell's axon is indicated by an arrow. There are no obvious differences in the dendritic morphology of cells in the nondeprived and deprived retina. 


\section{NORMAL EYE}
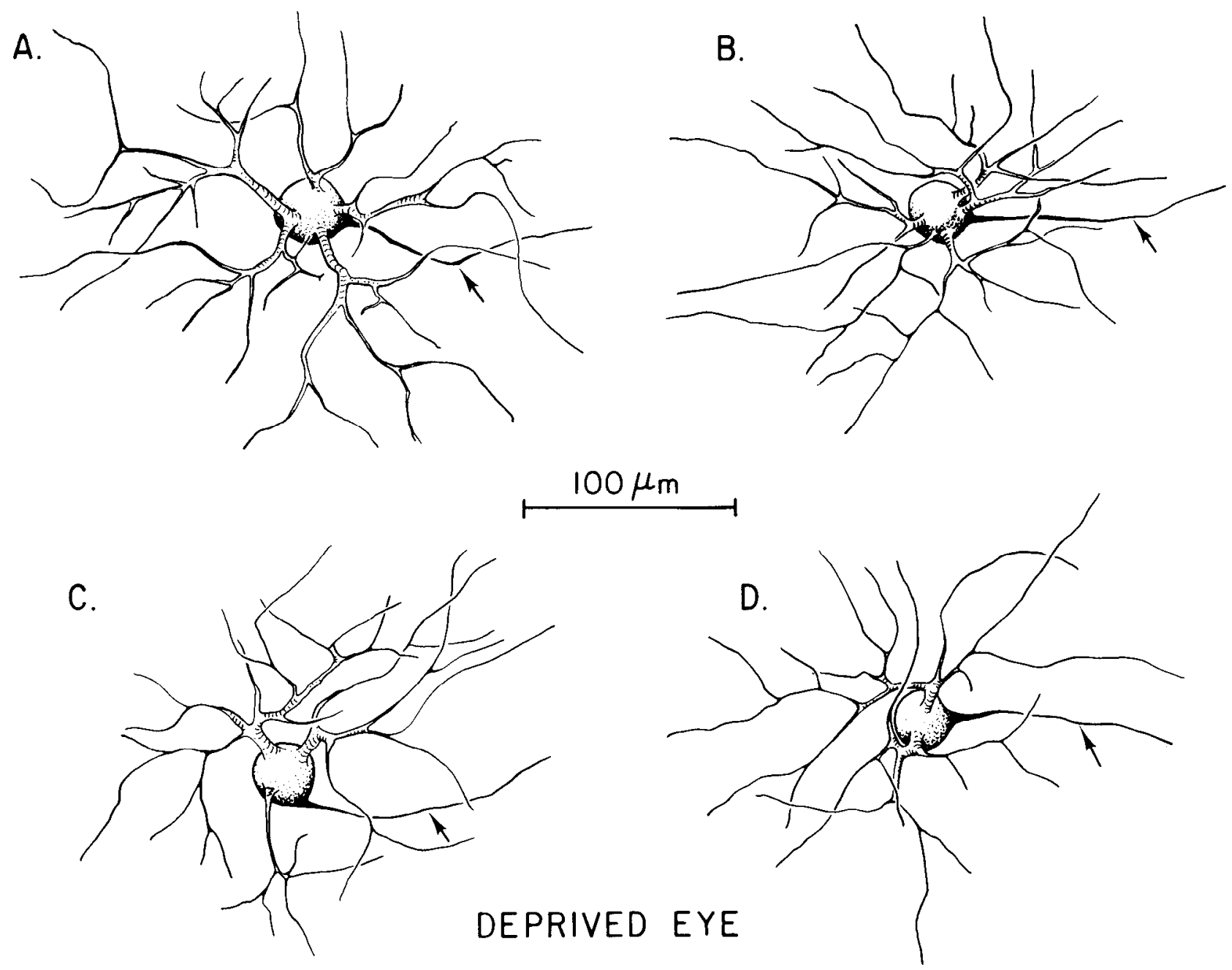

Figure 5. Camera lucida drawings of beta cells labeled by injections of HRP into the nondeprived and deprived A laminae of cat MD3. Conventions are as in Figure 5.

the dendritic field diameters and dendritic branching patterns of alpha and beta cells in the deprived retina were not obviously different from those in the nondeprived retina or from those of cells labeled by injections into laminae $\mathrm{A}$ and $\mathrm{A} 1$ of the LGNd of normal cats (Leventhal, 1982). For example, in normal and deprived temporal retina 5 to $7 \mathrm{~mm}$ from the area centralis, the dendritic field diameters of alpha cells ranged from 600 to $700 \mu \mathrm{m}$ and that of beta cells ranged from 170 to 230 $\mu \mathrm{m}$. These values are consistent with those reported for HRP-stained alpha and beta cells in normal cats (Leventhal, 1982). Of course, we cannot rule out the possibility that MD has a small effect upon dendritic morphology which is not evident in our HRP-stained material.

Axon measurements. In two long-term MD cats, the axons of alpha and beta cells were stained well enough to permit quantitative comparisons between corresponding samples of cells in the normal and deprived eyes. At the level of resolution provided by the light microscope, no differences were observed in the diameters of the axons of cells in the deprived and nondeprived retinae. For example, in both the deprived and nondeprived nasal retina, most alpha cell axons had diameters of 1.3 to 1.6 $\mu \mathrm{m}$ and most beta cell axons had diameters of 0.7 to 0.9 $\mu \mathrm{m}$.

\section{Discussion}

Prolonged monocular deprivation affects the sizes of both alpha and beta cells in the retina of the cat. The effects are different in portions of the retina projecting to binocular and monocular segments of the A laminae. Our results indicate that the cell bodies of both alpha and beta cells projecting to the binocular segments of laminae $\mathrm{A}$ and $\mathrm{A} 1$ are smaller in the deprived retina than in the nondeprived retina. In contrast, alpha cells in the deprived retina projecting to the monocular segment of lamina $\mathrm{A}$ are not smaller than their counterparts in the nondeprived retina. There is some evidence that beta cells in the deprived retina projecting to the monocular segment are smaller than corresponding cells in the nondeprived retina. However, these differences are small and only convincing in long-term MD cats. Similarly, following prolonged periods of $\mathrm{MD}$, beta cells in the deprived retina projecting to the binocular segments of laminae A 
and Al seem to be affected more seriously than neighboring alpha cells.

These results suggest that at least two factors may affect the sizes of retinal ganglion cells in the cat. First, it seems clear that the effects of competition between the two eyes for control of the geniculocortical pathways are reflected in the sizes of alpha and beta cells: both alpha and beta cells projecting to the binocular segment of lamina A are affected more severely by MD than alpha and beta cells projecting to the monocular segment of lamina A. Second, some other factor, such as the deprivation produced by monocular lid suture, or a competition between neighboring alpha and beta cells, may also be reflected in the sizes of beta cells but not in the sizes of alpha cells: beta cells but not alpha cells projecting to the monocular segment of lamina $\mathrm{A}$ are smaller in the deprived retina than in the nondeprived retina.

Variability among animals. In the 2.5-month-old kitten studied but not in the long-term MD cats, beta cells in the deprived retina projecting to the monocular segment of lamina A were not significantly smaller than their normal counterparts. Also, the areas of alpha and beta cells in the deprived retina projecting to the binocular segment of lamina A were shrunken to the same extent in the MD kitten, but beta cells were more shrunken than alpha cells in all four long-term MD cats. These differences could have been a result of random variation. Significant variation has been reported in the LGNd of MD cats (Hickey, 1980). On the other hand, it may be that the small changes due directly to the deprivation or to some other factor, such as a competition between alpha and beta cells, develop in the far nasal retina only after prolonged periods of MD. In long-term MD cats, deprivation-induced changes may serve to compound changes due to binocular competition already present in regions subserving binocular vision. A similar suggestion has been made to explain the differences in the effects of MD upon the binocular and monocular segments of the A laminae (Hickey et al., 1977). Additional studies of the effects of short pcriods of MD upon the retina are needed to determine whether this is the case. In any event, the absence of any significant effect in the far nasal retina in the MD kitten serves to strengthen the suggestion that cells projecting to the binocular segments of the A laminae are affected more severely than those projecting to the monocular segment.

Correlation with physiological studies. Considerable evidence indicates that there are correspondences between the morphological class of retinal ganglion cells, alpha, and the physiological class of retinal ganglion cells, $\mathrm{Y}$, as well as between the morphological class, beta, and the physiological class, X (Boycott and Wässle, 1974; Cleland et al., 1976). Given these correspondences, our findings show that $\mathrm{MD}$ affects both retinal $\mathrm{Y}$ and $\mathrm{X}$ cells and that X cells may be affected more by MD than $\mathrm{Y}$ cells.

The effects of MD on retinal $\mathrm{Y}$ and $\mathrm{X}$ cells thus are not the same as the reported differential effects of MD on LGNd Y and X cells. Sherman et al. (1972) have found that the relative number of $Y$ cells in the A laminae is reduced in MD cats, although the relative number of $Y$ cell axons present in the optic radiation may be normal
(Eysel et al., 1979). Since MD does not affect alpha cells more than beta cells, our results indicate that a reduction in the proportion of $\mathrm{Y}$ cells in the $\Lambda$ laminac must reflect changes central to the retina. Furthermore, we have not observed a reduction in the relative number of alpha cells projecting to the deprived A laminae. It is interesting, however, that LGNd Y cells are affected in the binocular but not in the monocular segments of the A laminae (Sherman et al., 1972, 1975), while the spatial resolution (Lehmkuhle et al., 1980) of X cells is affected in both segments. In a general way, the pattern of these changes corresponds with the morphological changes reported here.

Factors responsible for the reduced cell body sizes of alpha and beta cells. The patterns of axonal branching and arborization of retinal Y (alpha) cells and retinal X (beta) cells may help to account for the susceptibility of these cell types to MD. The axonal arborizations of $\mathrm{Y}$ cells are large, spread horizontally (up to $400 \mu \mathrm{m}$ ), and tend to concentrate in the lower part of the geniculate A lamina in which they terminate; most Y cell axons branch and project to a number of sites in addition to the $\mathrm{A}$ laminae. 'The axonal arborizations of retinal X cells are relatively narrow, cylindrical in shape, and oriented perpendicular to the A lamina in which they terminate; very few X cell axons branch and project to sites other than the A laminae (Stanford et al., 1981; Bowling and Michael, 1981). If visual deprivation does not alter these normal patterns of axonal branching and arborization, then shrinkage of the deprived A laminae should reduce the extent of the arborizations of both alpha and beta cells. This reduction should be greatest in the binocular segment of the nucleus where the reduction in laminar width is greatest (Table I) and cells projecting there should show the greatest changes. The arborizations of beta cells may be affected more than those of alpha cells by changes in the geniculocortical pathways because most individual $Y$ (alpha) cells but not X (beta) cells branch and project to multiple sites in addition to the $\mathrm{A}$ laminae (Stanford et al., 1981; Bowling and Michael, 1981). Thus, alpha and beta cells in the deprived retina of MD cats may have smaller cell bodies because they support reduced axonal arborizations, and differences between alpha and beta cells are to be expected in view of the differences in the patterns of their axonal branching. Reductions in the cell body sizes of relay cells in the deprived A laminae of the LGNd in MD cats may also result from changes in axonal arborizations (Guillery and Stelzner, 1970). Autoradiographic studies of the ocular dominance columns in the visual cortex of MD animals (Hubel et al., 1976; Shatz and Stryker, 1978) suggest that MD can affect the axonal arborizations of geniculate cells.

Functional significance. MD has profound behavioral effects (Dews and Wiesel, 1970; Ganz et al., 1972; Sherman, 1973), but there is no evidence that these reflect physiological changes in the retina. All of the receptive field types found in normal cats are present in the deprived retina of MD cats (Sherman and Stone, 1973) and the spatial resolution of ganglion cells in the deprived retina of MD cats appears normal (Kratz et al., 1979; Cleland et al., 1980). The morphological changes pro- 
duced in the retina by MD thus may not significantly alter the physiological properties of these cells. In view of this, it is worth emphasizing that although the cell body sizes of alpha and beta cells are reduced by MD, the changes produced in the retina seem much less severe than those produced in the LGNd. Prolonged lid suture does not appear to alter significantly the characteristic dendritic morphology, axon gauge, or cell body shape of alpha and beta cells (Figs. 4 and 5). The present findings, therefore, need not be viewed as incompatible with those of others who have found that the receptive field properties of retinal ganglion cells are not affected by MD. The functional significance, if any, of the small changes in the retina remain to be determined.

Conclusion. This study provides one of the few descriptions in the mammalian central nervous system of differential effects of sensory deprivation upon morphologically identified groups of cells whose functional identity is known. In particular, evidence is provided that alpha and beta cells and thus, presumably, retinal $\mathrm{Y}$ and $\mathrm{X}$ cells are affected differently by MD. Since LGNd Y and X cells (Sherman et al., 1972, 1975; Friedlander et al., 1982) as well as cortical cells receiving afferents from these cell types (Leventhal and Hirsch, 1977, 1980) also appear to be affected differently by visual deprivation, it seems that, at a number of points along the retinogeniculocortical pathways, $\mathrm{Y}$ and $\mathrm{X}$ cells have different requirements for postnatal visual stimulation. Some of these differences may reflect differences in the axonal branching and arborizations of $\mathrm{Y}$ and $\mathrm{X}$ cells in the retina and LGNd. For the most part, however, the factors underlying differences between $\mathrm{Y}$ and $\mathrm{X}$ cells, as well as their functional significance, remain obscure. Additional studies of the effects of visual deprivation upon different classes of retinal ganglion cells and the parallel pathways to which they give rise should clarify how early experience exerts its selective effects in the developing nervous system.

\section{References}

Bowling, D. B., and D. R. Michael (1981) Termination patterns of single optic tract axons of different physiological types. Soc. Neurosci. Abstr. 7: 25.

Boycott, B. B., and H. Wässle (1974) The morphological types of ganglion cells of the domestic cat's retina. J. Physiol. (Lond.) 140: 397-419.

Cleland, B. G., M. W. Dubin, and W. R. Levick (1971) Sustained and transient neurons in the cat's retina and lateral geniculate nucleus. J. Physiol. (Lond.) 217: 473-496.

Cleland, B. G., W. R. Levick, R. Morstyn, and H. G. Wagner (1976) Lateral geniculate relay of slowly conducting retinal afferents to cat visual cortex. J. Physiol. (Lond.) 255: 299 320 .

Cleland, B. G., D. E. Mitchell, S. Gillard-Crewther, and D. P. Crewther (1980) Visual resolution of ganglion cells in monocularly-deprived cats. Brain Res. 192: 261-266.

Dews, P. B., and T. N. Wiesel (1970) Consequences of monocular deprivation visual behavior in kittens. J. Physiol. (Lond.) 206: 437-455.

Eysel, U., O. Grusser, and K. P. Hoffmann (1979) Monocular deprivation and the signal transmission by $\mathrm{X}$ and $\mathrm{Y}$ neurons of the cat lateral geniculate nucleus. Exp. Brain Res. 34: 521540.
Friedlander, M. J., L. R. Stanford, and S. M. Sherman (1982) Effects of monocular deprivation on the structure-function relationship of individual neurons in the cat's lateral geniculate nucleus. J. Neurosci. 2: 321-331.

Ganz, L., H. V. B. Hirsch, and S. B. Tieman (1972) The nature of perceptual deficits in visually deprived cats. Brain Res. 44: $547-568$.

Guillery, R. W., and D. J. Stelzner (1970) The differential effects of unilateral lid closure upon the monocular and binocular segments of the dorsal lateral geniculate nucleus. J. Comp. Neurol. 139: 413-422.

Hickey, T. L. (1980) Development of the dorsal lateral geniculate nucleus in normal and visually deprived cats. J. Comp. Neurol. 189: 467-481.

Hickey, T. L., P. D. Spear, and K. D. Kratz (1977) Quantitative studies of cell size in the cat's dorsal lateral geniculate nucleus following visual deprivation. J. Comp. Neurol. 172: 265-281.

Hirsch, H. V. B., and A. G. Leventhal (1978) Functional modification of the developing visual system. In Handbook of Sensory Physiology: Development of Sensory Systems, M. Jacobson, ed., pp., 279-335. Springer-Verlag, Berlin.

Hoffmann, K. P., J. Stone, and S. M. Sherman (1972) Relay of receptive-field properties in dorsal lateral geniculate nucleus of the cat. J. Neurophysiol. 35: 518-531.

Hubel, D. H., T. N. Wiesel, and S. LeVay (1976) Functional architecture of area 17 in normal and monocular deprived macaque monkeys. Cold Spring Harbor Symp. Quant. Biol. 40: 581-589.

Kalil, R. (1980) A quantitative study of the effects of monocular enucleation and deprivation on cell growth in the dorsal lateral geniculate nucleus of the cat. J. Comp. Neurol. 189: 483-524.

Kratz, K. E., S. C. Mangel, S. Lehmkuhle, and S. M. Sherman (1979) Retinal X-and Y-cells in monocular lid-sutured cats: Normality of spatial and temporal properties. Brain Res. 172: $545-551$.

Lehmkuhle, S. W., K. E. Kratz, S. C. Mangel, and S. M. Sherman (1980) Effects of early monocular lid-suture on spatial and temporal sensitivity of neurons in dorsal lateral geniculate nucleus of the cat. J. Neurophysiol. 43: 542-556.

Leventhal, A. G. (1982) Morphology and distribution of retinal ganglion cells projecting to different layers of the dorsal lateral geniculate nucleus in normal and Siamese cats. $\mathrm{J}$. Neurosci. 2: 1024-1042.

Leventhal, A. G., and H. V. B. Hirsch (1977) Effects of early experience upon the orientation and sensitivity and the binocularity of neurons in the cat visual cortex.Proc. Natl. Acad. Sci. U. S. A. 74: 1271-1276.

Leventhal, A. G., and H. V. B. Hirsch (1980) Receptive-field properties of different classes of neurons in visual cortex of normal and dark-reared cats. J. Neurophysiol. 43: 1111-1132.

Leventhal, A. G., R. W. Rodieck, and B. Dreher (1981) Morphology and central projections of different types of retinal ganglion cells in cat and old-world monkey ( $M$. fasicularis). Soc. Neurosci. Abstr. 7: 582.

Sanderson, K. J. (1971) The projection of the visual field to the lateral geniculate and medial interlaminar nuclei in the cat. J. Comp. Neurol. 143: 101-118.

Shatz, C. J., and M. P. Stryker (1978) Ocular dominance in layer 4 of the cat's visual cortex and the effects of monocular deprivation. J. Physiol. (Lond.) 281: 267-283.

Sherman, S. M. (1973) Visual field deficits in monocularly and binocularly deprived cats. Brain Res. 49: 25-45.

Sherman, S. M., and J. Stone (1973) Physiological normality of the retina in visually deprived cats. Brain Res. 60: 224-230.

Sherman, S. M., K. -P. Hoffmann, and J. Stone (1972) Loss of a specific cell type from the dorsal lateral geniculate nucleus in visually deprived cats. J. Physiol. (Lond.) 35: 532-541. 
Sherman, S. M., J. R. Wilson, and R. W. Guillery (1975) Evidence that binocular competition affects the postnatal development of Y-cells in the cat's lateral geniculate nucleus. Brain Res. 100: 441-444.

Stanfori, L. R., M. Sur, and S. M. Sherman (1981) Terminal morphology of physiologically identified X and Y optic tract axons within the lateral geniculate nucleus of the cat. Soc. Neurosci. Abstr. 7: 25

Stone, J., A. G. Leventhal, C. R. R. Watson, J. Keens, and R. Clarke (1980) Gradients between nasal and temporal areas of cat retina in the properties of retinal ganglion cells. J. Comp.
Neurol. 192: 219-235.

Weisel, T. N., and D. H. Hubel (1963) Single-cell responses in striate cortex of kittens deprived of vision in one eye. J. Neurophysiol. 26: 1003-1017.

Weisel, T. N., and D. H. Hubel (1965) Comparison of the effects of unilateral and bilateral eye closure on cortical unit responses in kitten. J. Neurophysiol. 28: 1029-1040.

Wilson, P. E., M. H. Rowe, and J. Stone (1976) Properties of relay cells in the cat's lateral geniculate nucleus. A comparison of W-cells with X-and Y-cells. J. Neurophysiol. 38: 11931209. 